\title{
МОДЕЛИ ЗЕМНОЙ КОРЫ ПО ДАННЫМ ПОТЕНЦИАЛЬНЫХ ПОЛЕЙ
}

\author{
М.С. Чадаев \\ Горный институт УрО РАН, г. Пермь
}

\begin{abstract}
Аннотация: Важным объектом изучения земной коры служит петрофизическая и геологическая граница Мохо, разделяющая земную кору и верхнюю мантию Земли. Рядом исследователей допускается наличие фазового перехода вещества пород верхней мантии (габбро-эклогит, базальт-перидотит). Рассматриваются вопросы комплексирования сейсморазведки с данными гравитационного, магнитного, теплового и других потенциальных полей, а также с использованием изотопно-геохимических критериев. Мощность, вещественный состав коры, глубина и морфология границы Мохо определяют тип коры. На шельфе установить континентальный тип коры требуется для обоснования права на претендуемую часть шельфа.

Ключевые слова: граница Мохо, обрабатывающая система ВЕКТОР, сейсморазведка (ГСЗ), гравиметрия, магниторазведка.
\end{abstract}

Метод глубинного сейсмического зондирования (ГС3) получил главенствующее положение на континенте, включая область шельфа, и акваторию [3-6]. Наибольшую мощность земная кора имеет в горах, до 70 км, а наименьшую - на дне океанов, порядка 10 км в связи с существенным сокращением гранитного и базальтового слоёв.

Структурные карты поверхности Мохо позволяют закартировать крупные тектонические элементы, оценить их связь с вышезалегающими объектами, а также спрогнозировать закономерности размещения полезных ископаемых, индикаторами которых зачастую служат глубинные разломы. Изучаются также вопросы комплексирования сейсморазведки с другими геофизическими методами, а также использования изотопногеохимических критериев [1]. Однако идея совместного применения сейсморазведки и гравиразведки является ключевой, чему в большой мере способствует наличие банков гравиметрической информации.

Развитие теории абиогенного происхождения углеводородов - углеводородный синтез - происходит, по сути, с интенсификацией изучения глубинного строения земной коры [2].

Создан ряд современных систем глобальных карт Мохо сейсмических, комбинированных и гравиметрических [4-6]: European Moxo (2009) (28 N-86 N, 40 W-70 E); Australian Moxo (2011) (10 S-45 S-110 E-160 E); North America Moxo (2009) (30 N-50N, 70 W-100 W); Jtaly Moхо (2010) - комбинация двух моделей CRUST2.0 model and GOCE data (Gravity field and steady-state Ocean Circulation Explorer - спутник для исследования гравитационного поля). Известны также гравиметрические российские системы: комплексная плотностная модель литосферы (Воронежский университет); сканирующая система ВЕКТОР (Горный институт УрО РАН).

На основе системы Воронежского университета создана [2], Петроплотностная карта докембрийского фундамента Воронежского кристаллического массива (2020 г.). Система ВЕКТОР использовалась для картирования границы Мохо на северо-западе Русского Севера (Русская и Печорская плиты), а также на шельфе и на море.

Ниже в качестве иллюстрации приведены примеры обработки данных гравиметрии и магнитометрии в системе ВЕКТОР.

\section{ФЕННОСКАНДИНАВСКИЙ ЩИТ}

Разрез гравиметрического куба 3D диаграммы в системе ВЕКТОР по линии примерно на широте $60^{\circ}$ с. ш. через известные глубинные структуры (с запада на восток): плато Телемарк, Бергслаген, Выборгская, Ладожская и Онежская приведен [2] на рис. 1. 


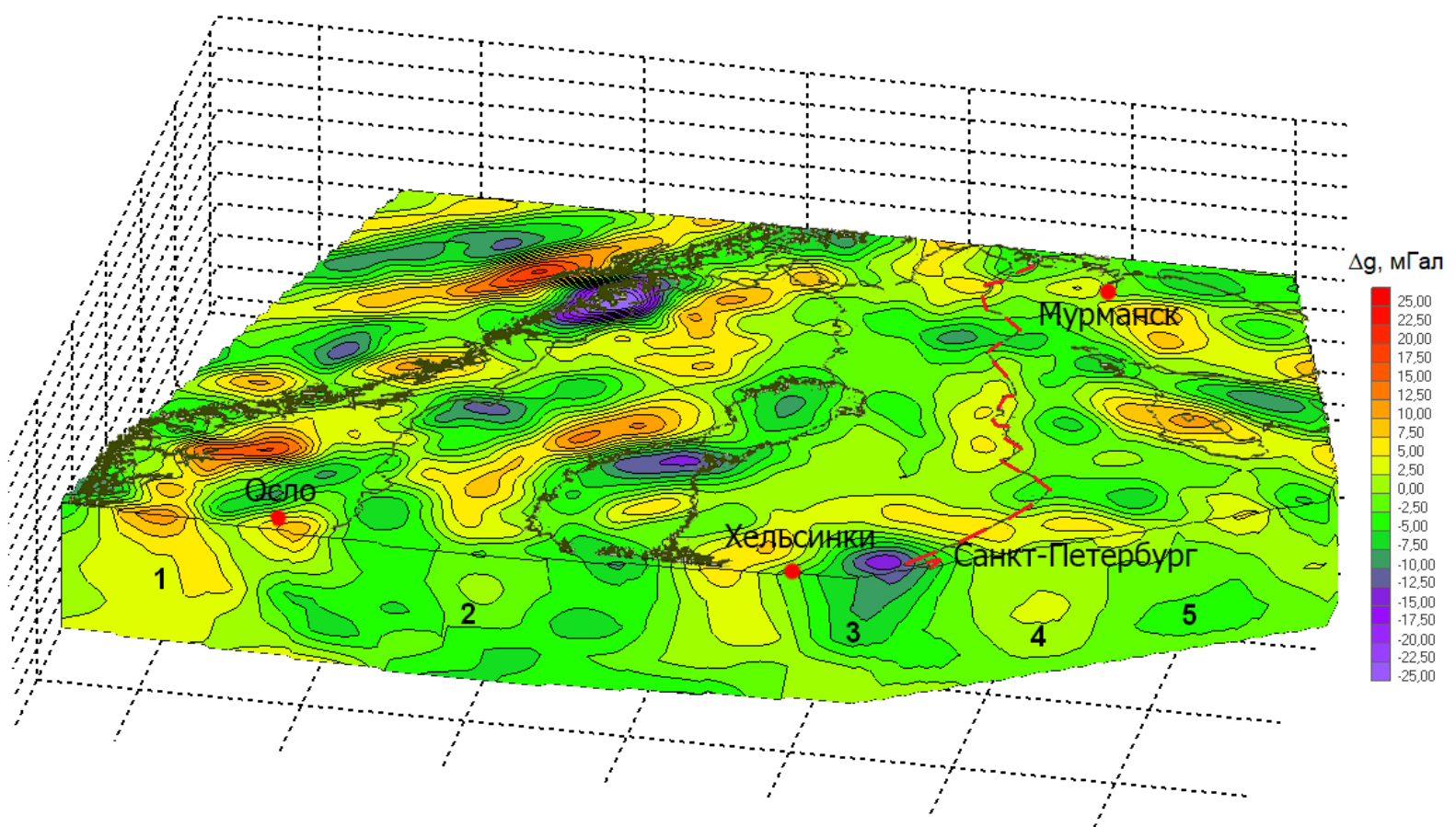

Рис. 1. Горизонтальный и вертикальный срезы диаграммы аномалий силы тяжести в системе ВЕКТОР. Фенноскандинавский щит. Глубинные структуры: 1 - Телемарк, 2 - Бергслаген, 3 - Выборгская, 4 - Ладожская, 5 - Онежская. Красной линией показана государственная граница

Зона относительно повышенного залегания границы Мохо на рассматриваемом блоке пород (рис. 1) выделяется изоглубинами с отметками порядка 38 км.

В векторном отображении данные структуры, характеризуемые в работе (А.П. Светов, Л.П. Свириденко, 2001) как сводовые и депрессионные, исходя из их формы и интенсивности, а также глубины источников аномалий, проявляются неодинаково.

Плато Телемарк проявляется высокоинтенсивной положительной аномалией 1 , составляя часть скалистых Скандинавских гор, и находится в районе сильных землетрясений. Структура Бергслаген характеризуется близкой к нулевым значениям положительной аномалией 2 , Выборгская - высокоинтенсивная отрицательная аномалия 3 , Ладожская 4 и Онежская 5 - слабо интенсивные положительные. Массивы трещиноватых гранитов рапакиви (rapakivi granitoids - гнилой камень) характеризуются отрицательными аномалиями.

\section{ВОСТОЧНО-ЕВРОПЕЙСКАЯ ПЛАТФОРМА (ВЕП)}

Рис. 2 характеризует район северо-западной территории ВЕП: Печорская и Русская плиты.

Трансформированное магнитное поле на территории Русской плиты отчётливо имеет мозаичную структуру. При этом обособленно выделяется северо-западного направления линейная цепочка аномалий - Западно-Тиманский глубинный разлом, разделяющий Печорскую и Русскую плиты. В его зоне (северо-восточная часть Мезенской седловины) находится высокоинтенсивная магнитная аномалия, получившая название по гравиметрическим исследованиям «Мезенский гравитационный максимум» (М.Г. Губайдуллин, А.М. Онякова, 2020).

На территории Печорской плиты аномалии магнитного поля менее интенсивно проявляются, чем на Русской. 


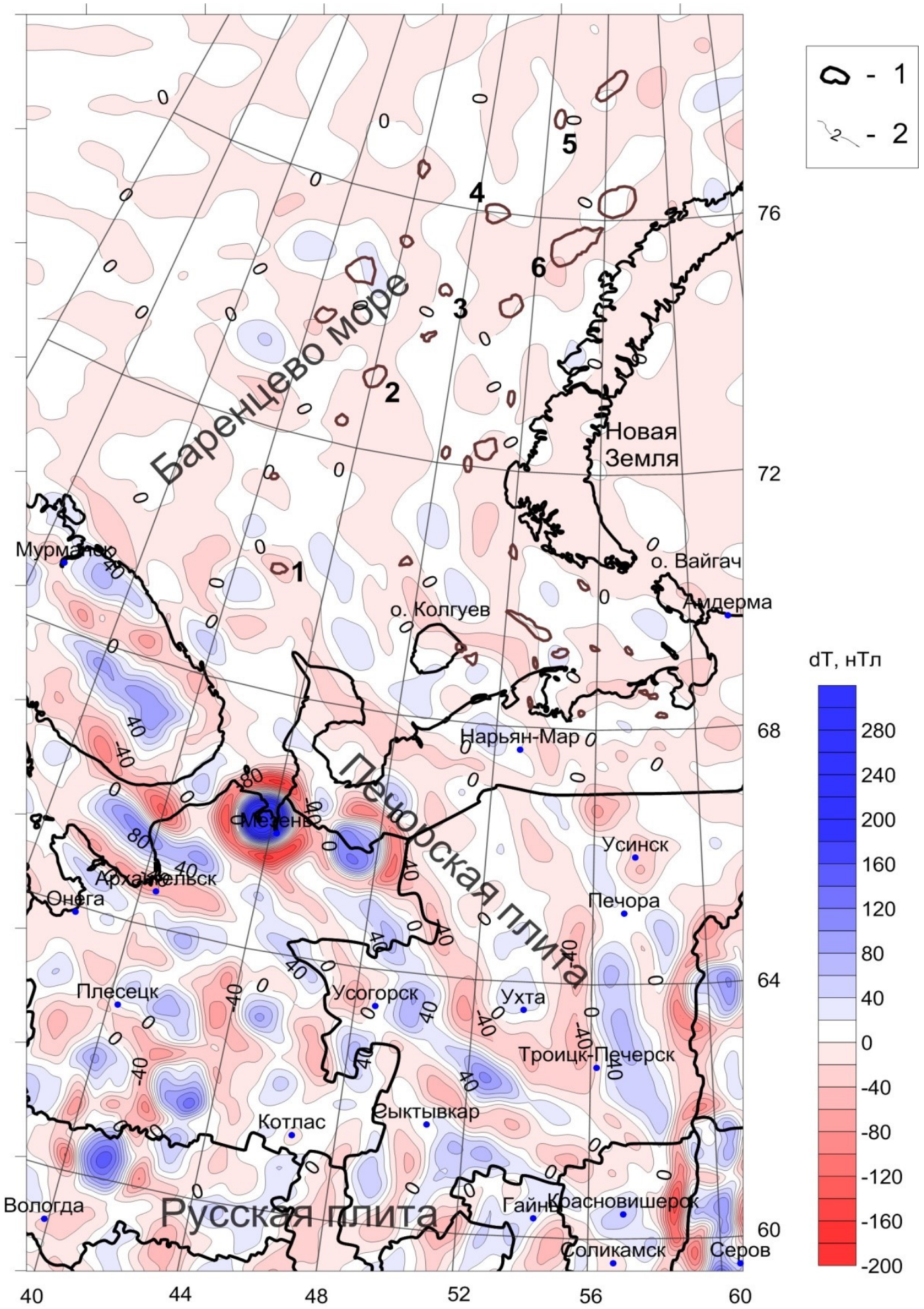

Рис. 2. Горизонтальный срез трехмерной диаграммы магнитного поля $\Delta \mathrm{T}$, полученной по системе ВЕКТОР и отражающий структурные особенности пород верхней и средней частей земной коры:

1 - локальные структуры и месторождения; 2 - изолинии трансформанты магнитного поля, нТл

\section{Выводы}

Кратко перечислены современные системы обработки и интерпретации гравиметрических и магнитных данных при изучении земной коры, в первую очередь границы Moxo. 
Приведённые результаты получены для территории Европейского севера России при помощи системы ВЕКТОР, разработанной в Горном институте УрО РАН. Гравиметрические и магнитные построения сопоставлены с сейсмическими моделями.

Система ВЕКТОР позволяет получить информационный куб квазиплотностного параметра изучаемой среды, то есть картину строения недр, локализовать источники аномалий, соотнести между собой их глубину, размеры и затем выдать рекомендации для практического использования при выделении поисковых объектов, перспективных на выявление залежей нефти и газа и рудных полезных ископаемых.

К рассматриваемой области следует отнести и способы, позволяющие создать глобальные модели: способ аналитического продолжения аномалий силы тяжести для построения контактной поверхности, способ построения поверхности раздела сред с аномальными плотностями путём решения прямой и обратной задач (Россия).

Информационный куб квазиплотностного параметра изучаемой среды в системе ВЕКТОР позволяет получить картину, отождествляемую с геологическим строением недр, локализовать и соотнести между собой источники аномалий по размерам и по глубине и затем выдать рекомендации.

Район исследований - Европейский север России, часть Арктического сегмента Земли - имеет недостаточную геолого-геофизическую изученность. Основное внимание в статье уделено применению методов гравиметрии. Структурные гравиметрические и магнитные построения сопоставлены с моделью European Moho.

На основании вышеизложенного можно констатировать, что связи полученного в системе ВЕКТОР поля $\Delta \mathrm{g}$ с неоднородностями строения нижней части земной коры позволяют проследить в пространстве границу масс, отождествляемую с поверхностью Moxo.

\section{БИБЛИОГРАФИЧЕСКИЙ СПИСОК}

1. Малышева Л.К., Малышев А.И. Углеводороды и дегазационные процессы Титана, спутника Сатурна // Литосфера. - 2020. - Т. 20. - № 6. - С. 873-895. - DOI: 10.24930/1681-9004-2020-20-6-873-895.

2. Глазнев В.Н., Минц М.В., Муравина О.М. Плотностное моделирование земной коры центральной части Восточно-Европейской платформы // Вестн. КРАУНЦ. Сер. Науки о Земле. - 2016. - № 1 (29). - C. 53-63.

3. Чадаев М.С., Костицын В.И., Гершанок В.А., Тарантин М.В., Простолупов Г.В. Геофизические исследования земной коры Европейского севера / под общ. ред. М.С. Чадаева; ПГНИУ, ГИ УрО РАН. Пермь, 2020. - 99 с.

4. Шаров Н.В. Литосфера Северной Европы по сейсмическим данным. - Петрозаводск: Карельский науч. центр РАН, 2017. - 168 с.: ил.

5. Reguzzoni M., Sampietro D., Sanso F. Global Moxo from the combinanation of the CRUST2.0 model and GOCE data // Geophysical journal international. - V. 195, № 1. - P. 222-237. - DOI: 10.1093/gji/ggt247.

6. Grad, M., Tiira, T. The Moho depth map of the European Plate // Geophysical journal international. - 2009. - V. 176, № 1. - C. 279-292. - DOI: 10.1111/j.1365-246X.2008.03919.x. 